\title{
Anti-inflammatory activity of aqueous extract and bioactive compounds identified from the fruits of Hancornia speciosa Gomes (Apocynaceae)
}

Manoela Torres-Rêgo', Allanny Alves Furtado', Mariana Angélica Oliveira Bitencourt', Maira Conceição Jerônimo de Souza Lima', Rafael Caetano Lisbôa Castro de Andrade', Eduardo Pereira de Azevedo ${ }^{2}$, Thaciane da Cunha Soares ${ }^{3}$, José Carlos Tomaz ${ }^{4}$, Norberto Peporine Lopes ${ }^{4}$, Arnóbio Antônio da Silva-Júnior ${ }^{1}$, Silvana Maria Zucolotto ${ }^{3}$ and Matheus de Freitas Fernandes-Pedrosa ${ }^{1 *}$

\begin{abstract}
Background: Hancornia speciosa Gomes (Apocynaceae), popularly known as "mangabeira," has been used in folk medicine to treat inflammatory disorders, hypertension, dermatitis, diabetes, liver diseases and gastric disorders. Although the ethnobotany indicates that its fruits can be used for the treatment of ulcers and inflammatory disorders, only few studies have been conducted to prove such biological activities. This study investigated the anti-inflammatory properties of the aqueous extract of the fruits of $\mathrm{H}$. speciosa Gomes as well as its bioactive compounds using in vivo experimental models.
\end{abstract}

Methods: The bioactive compounds were identified by High Performance Liquid Chromatography coupled with diode array detector (HPLC-DAD) and Liquid Chromatography coupled with Mass Spectrometry (LC-MS). The antiinflammatory properties were investigated through in vivo tests, which comprised xylene-induced ear edema, carrageenan-induced peritonitis and zymosan-induced air pouch. The levels of IL-1 $\beta, I L-6, I L-12$ and TNF-a were determined using ELISA.

Results: Rutin and chlorogenic acid were identified in the extract as the main secondary metabolites. In addition, the extract as well as rutin and chlorogenic acid significantly inhibited the xilol-induced ear edema and also reduced the cell migration in both carrageenan-induced peritonitis and zymosan-induced air pouch models. Reduced levels of cytokines were also observed.

Conclusion: This is the first study that demonstrated the anti-inflammatory activity of the extract of $\mathrm{H}$. speciosa fruits against different inflammatory agents in animal models, suggesting that its bioactive molecules, especially rutin and chlorogenic acid are, at least in part, responsible for such activity. These findings support the widespread use of Hancornia speciosa in popular medicine and demonstrate that its aqueous extract has therapeutical potential for the development of herbal drugs with anti-inflammatory properties.

Keywords: Anti-inflammatory, Apocynaceae, Chlorogenic acid, Hancornia speciosa, Mangabeira, Rutin

\footnotetext{
* Correspondence: mpedrosa@ufrnet.br

'Departamento de Farmácia, Laboratório de Tecnologia e Biotecnologia Farmacêutica (TecBioFar), Faculdade de Farmácia, Centro de Ciências da Saúde, Universidade Federal do Rio Grande do Norte, Rua Gal. Gustavo Cordeiro de Farias, s/n, Petrópolis, CEP 59012-570 Natal, RN, Brazil Full list of author information is available at the end of the article
} 


\section{Background}

The use of plants is a common practice in Brazil's folk medicine and it has been based on the build-up of empirical knowledge by various ethnic groups about the therapeutic effect of these herbal plants [1]. These medicinal plants are widely used for research of new drugs as they represent a rich source of compounds with pharmacological properties [2]. Since these plants are naturally found in relative abundance in Brazil, the population has easy access to these natural sources at relatively low cost and minimal side effects [3].

Hancornia speciosa Gomes, which belongs to the family of Apocynaceae and is popularly known as "mangabeira", is a fruit plant species native to Brazil [4]. It is found in the cerrado, caatinga and savanna vegetation [5]. In traditional medicine, its fruits have been used to treat ulcers, tuberculosis and inflammatory disorders [6], whereas the infusion of barks have been used for treating gastric ulcers, stomach disturbances and inflammatory processes [7]. In addition, its roots and leaves are used to treat high blood pressure and rheumatism $[8,9]$. Hancornia speciosa leaves have been demonstrated to exhibit anti-hypertensive [10-12], anti-carcinogenic [13, 14] and anti-diabetic properties [15]. Its barks have a marked gastroprotective effect and anti-Helicobacter pylori activity $[16,17]$. However, there have been few studies that reported the pharmacological effects of Hancornia speciosa fruits and just recently, a group described the antimutagenic potential of its fruit pulp [18]. Its latex has shown anti-inflammatory effect through reduction of edema induced by bradykinin, histamine and serotonin, as well as by inhibiting inflammation induced by subcutaneous carrageenan injection and through inhibition of leukocytes migrations, nitric oxide, PGE2 and cytokines production in mice [19]. Therefore, the anti-inflammatory effect of Hancornia speciosa latex corroborated the popular use of its fruits for the treatment of ulcers and inflammatory disorders.

Inflammation is an immune system response triggered by different stimuli, including chemical, physical and biological [20]. The recognition of a harmful agent or stimulus triggers the activation and amplification of the immune response, resulting in cell activation and release of various mediators responsible for the inflammatory response [21]. Among these mediators, cytokines (IL-1 $\beta$, IL-6, IL-12 and TNF- $\alpha$ ) are noteworthy as they are responsible for inducing the expression of adhesion molecules and for inducing leukocytes sequestration from the blood stream towards the inflammation site [22]. Therefore, when the inflammatory process is not controlled, it can cause tissue damage [23]. In order to control the inflammation process, drugs that inhibit this clinical condition, such as non-steroidal anti-inflammatory and steroidal anti-inflammatory drugs are used. However, the overuse of non-steroidal anti-inflammatory drugs can cause side-effects such as gastrointestinal and cardiovascular complications [24], whereas the steroidal antiinflammatory drugs may cause reduced resistance to infections, aggravation of ulcers and osteoporosis [25]. On the other hand, studies have shown that plants are able to reduce the inflammatory process with considerably less side-effects. For instance, some vegetal extracts are able to reduce the total number of leukocytes, to decrease the secretion of cytokines and histamine, as well as to reduce the proliferation of lymphocytes [26, 27]. Given the importance of these biological properties, traditional medicinal knowledge along with modern techniques have optimized the process of drug discovery from medicinal plants $[28,29]$.

Based on the fact that only few studies have reported the pharmacological properties of $H$. speciosa fruits, despite its widespread popular use as an anti-inflammatory agent, this work aims to investigate the chemical constituents of these fruits and associate its major compounds with the anti-inflammatory effect. Therefore, phytochemical analysis of the aqueous extract of the fruits of $H$. speciosa was performed in order to identify the bioactive compounds, followed by the evaluation of its antiinflammatory activity in experimental models using mice. The in vivo models were the (i) carrageenaninduced peritonitis, (ii) xylene-induced ear edema, and (iii) zymosan-induced air pouch model, where the (iv) production of cytokines (IL- $1 \beta$, IL-6, IL-12 and TNF- $\alpha$ ) was also evaluated. To the best of our knowledge, this is the first study that investigated the anti-inflammatory effect of the extract of the fruits of $H$. speciosa.

\section{Methods}

\section{Plant material}

The mature fruits were collected at Barra do Punaú region (lat:-5,34527 long:-35,41666), Rio do Fogo City, Rio Grande do Norte, Brazil, in March of 2011 and was identified by botanist Dr. Jomar Gomes Jardim. A voucher specimen (UFRN 16880) was deposited in the Herbarium of the Federal University of Rio Grande do Norte, Brazil. The collection of the plant material was conducted under authorization of the Brazilian Authorization and Biodiversity Information System (SISBIO) (process number 35017) and Brazilian Access Authorization and Dispatch Component of Genetic Patrimony (Process 010844/2013-9).

\section{Preparation of the aqueous extract}

Fresh fruits $(500 \mathrm{~g})$ were sliced in pieces and submitted to extraction by decoction using hot water at $100{ }^{\circ} \mathrm{C}$ (1:10, w:v, plant:solvent) for 15 min. Further, the extract was filtered through Whatman paper no.1 and lyophilized. The final dried mass was $2.5 \mathrm{~g}$ (yield around $0.5 \%)$. 
High Performance Liquid Chromatography coupled with diode array (HPLC-DAD) Analysis

Analyses were performed using HPLC Varian ${ }^{\circ}$ Pro Star 335 with diode array detector. A Phenomenex ${ }^{\circ}$ RP-18 column $(250 \times 4.6 \mathrm{~mm}, 5 \mu \mathrm{m})$ was used. The eluents were: (A) acetonitrile and (B) water with $0.3 \%$ acetic acid, with the following gradient $(\mathrm{v} / \mathrm{v}): 13 \%, 0-5 \mathrm{~min}$ (B); 13-18 \%, 5-25 min (B); 18-20\%, 25-30 min (B); 20-21\%, 30-35 $\mathrm{min}$ (B). Flow elution was $0.7 \mathrm{~mL} / \mathrm{min}$ and $20 \mu \mathrm{L}$ of each sample was injected. The lyophilized extract and standard solutions were resuspensed in methanol: water, $1: 1(\mathrm{v} / \mathrm{v})$ and the final concentrations were $5 \mathrm{mg} / \mathrm{mL}$ and $50 \mu \mathrm{g} / \mathrm{mL}$. The chromatogram was visualized in 270 and $340 \mathrm{~nm}$, where each peak and their retention time $\left(R_{t}\right)$ was compared with those of the standards. The peaks that showed similar UV and $R_{t}$ were analyzed by co-injection (reference standard + extract) with the purpose of observing any increase in the peak area. Samples and solvents were previously filtered through a $0.45 \mu \mathrm{m}$ membrane and degassed. Both rutin (purity $94 \%$ ) and chlorogenic acid (purity $95 \%$ ) were purchased from Sigma-Aldrich ${ }^{\circ}$, USA.

\section{Liquid Chromatography coupled with mass spectrometry (LC-MS) analysis}

High resolution analyses by LC-MS were performed on a Shimadzu LC-20 AD apparatus equipped with an autosampler (SIL-20A, Shimadzu), diode array detector (SPDM20AV, Shimadzu) and coupled with a micrOTOFII (Bruker Daltonics) ESI-qTOF mass spectrometer. The LC conditions were the same applied at High Performance Liquid Chromatography coupled with diode array (HPLCDAD) Analysis. The column eluent was split at a ratio of $7: 3$, where the larger flow went to the DAD detector and the lower one went to the mass spectrometer.

Low resolution applied a similar Shimadzu LC-20 AD apparatus coupled with an ESI-ion trap mass spectrometer (amaZon, Bruker Daltonics). Again, the LC conditions were the same as described on High Performance Liquid Chromatography coupled with diode array (HPLC-DAD) Analysis. The column eluent was split at a ratio of $7: 3$, where the larger flow went to the DAD detector and the lower one went to the mass spectrometer.

\section{Animals}

Male and female Swiss and BALB/c mice (25-35 g), 68 weeks of age, were maintained at a temperature of $22 \pm 2{ }^{\circ} \mathrm{C}$ and at a $12 / 12 \mathrm{~h} \mathrm{light/dark}$ cycle. Each test group was composed of five animals $(n=5)$. The experimental protocol was approved by the Committee for Ethics in Animal Experimentation of the Universidade Federal do Rio Grande do Norte, Brazil, at the Protocol $N^{\circ}$ 008/2011 and in accordance with the guidelines of
National Council for the Control of Animal Experimentation (CONCEA).

\section{Carrageenan-induced peritonitis model}

Peritoneal inflammation was induced according to the procedure previously described in [30] with few modifications. BALB/c mice were inoculated intravenously (i.v.) with $100 \mu \mathrm{L}$ of saline, aqueous extract of Hancornia speciosa fruits (20,30 or $40 \mathrm{mg} / \mathrm{kg})$, chlorogenic acid (2, 2.5 or $5 \mathrm{mg} / \mathrm{kg})$ or rutin $(2,2.5$ or $5 \mathrm{mg} / \mathrm{kg})$, while dexamethasone was injected intraperitoneally (i.p.) $(0.5 \mathrm{mg} / \mathrm{kg})$ and used as the anti-inflammatory reference drug. After $30 \mathrm{~min}$, the animals received carrageenan $(1 \mathrm{mg} / \mathrm{mL})$ or saline intraperitoneally. After $4 \mathrm{~h}$, the animals were euthanized with an overdose of xylazine and ketamine $(10 \mathrm{mg} /$ $\mathrm{kg}-100 \mathrm{mg} / \mathrm{kg}$ ) and peritoneal exudates were harvested by peritoneal lavage using $2 \mathrm{~mL}$ of saline, followed by centrifugation at $250 \mathrm{~g}$ for $10 \mathrm{~min}$ at $4{ }^{\circ} \mathrm{C}$. Leucocytes count was determined using a Neubauer chamber [31, 32]. The supernatants were collected for determination of IL-1 $\beta$, IL-6, IL-12 and TNF- $\alpha$ levels using an ELISA kit (eBioscience, USA) following the manufacturer's instructions.

\section{Xylene-induced ear edema model}

$\mathrm{BALB} / \mathrm{c}$ mice were treated intraperitoneally with $100 \mu \mathrm{L}$ of saline, dexamethasone $(0.5 \mathrm{mg} / \mathrm{kg})$, aqueous extract of Hancornia speciosa fruits $(40,50$ or $60 \mathrm{mg} / \mathrm{kg}$ ), rutin $(2.5,5$ or $10 \mathrm{mg} / \mathrm{kg})$ and chlorogenic acid $(10,12.5$ or $15 \mathrm{mg} / \mathrm{kg}$ ). Thirty minutes after the treatment, all the animals received $40 \mu \mathrm{L}$ of xylene administered in the anterior and posterior surfaces of the right ear. The left ear was taken as control where only saline was administered. Fifteen minutes after xylene administration, the animals were euthanized and both ears were cut off at circular sections of $7 \mathrm{~mm}$ using a cork borer and then weighed [33]. The edematous response was measured as the weight difference between the right and left ears, where the inhibition level was then calculated as:

$$
\text { Inhibition }(\%)=[1-\mathrm{Et} / \mathrm{Ec}] \times 100,
$$

where $E t$ and $E c$ are the average weight of the edemas in the sample-treated and control groups, respectively.

\section{Zymosan-induced air pouch model}

Swiss mice received $5 \mathrm{~mL}$ of sterile air subcutaneously (s.c.), which were injected into the back of the animals. After three days, $2.5 \mathrm{~mL}$ of sterile air was injected into the cavity. Six days after the initial air injection, the animals received intraperitoneal injection of saline, dexamethasone $(2.0 \mathrm{mg} / \mathrm{kg})$, aqueous extract of Hancornia speciosa fruits $(40,50$, or $60 \mathrm{mg} / \mathrm{kg})$, rutin $(2.5,5$ or $10 \mathrm{mg} / \mathrm{kg})$ and chlorogenic acid (10,12.5 or $15 \mathrm{mg} / \mathrm{kg})$ [33]. After $30 \mathrm{~min}$, zymosan solution $(1 \mathrm{mg} / \mathrm{mL})$ was injected into the air 
pouch. At pre-determined time points $(6,24$, and $48 \mathrm{~h})$, the animals were euthanized and exudates were harvested from each air pouch by washing with $2 \mathrm{~mL}$ of saline. Leucocytes count was determined using a Neubauer chamber [34-36]. The cell pellet was diluted in $500 \mathrm{~mL}$ of saline and the cell subpopulations count (polymorphonuclear and mononuclear cells) was determined based on the count of 100 cells using a hemocytometer [37].

\section{Statistical analysis}

Data are expressed as mean \pm standard deviation. Statistical analyses were performed by One-way ANOVA with Tukey's test and regression analyses were performed using GraphPad Prism version 5.00 (San Diego, CA, USA). A difference in the mean values of $P<0.05$ was considered as statistically significant.

\section{Results}

\section{HPLC-DAD analysis}

Analysis by HPLC-DAD showed the presence of chlorogenic acid (peak 1) and rutin (peak 2) in the aqueous extract of Hancornia speciosa fruit (Fig. 1). The standard solutions of these compounds were analyzed, showing retention times of 7.9 (solvent A: 87-82 \%) and $25.5 \mathrm{~min}$ (solvent A: 82-80\%), respectively, which are similar to peaks 1 and 2. In addition, UV spectrum of peaks 1 and 2 exhibited UV $\lambda_{\max }$ of 222 and $326 \mathrm{~nm}$ (peak 1) and 257 and $353 \mathrm{~nm}$ (peak 2), respectively, which were similar to the UV spectrum of chlorogenic acid and rutin. Through the co-injection analysis of the standards and the aqueous extract, an increase in the peak areas was observed, confirming the presence of these compounds. Although peak 3 was not identified, the UV spectrum suggests it is due to the presence of an unidentified phenolic acid (UV $\lambda_{\max } 223$ and $332 \mathrm{~nm}$ ) [38].

\section{LC-MS analysis}

Peak 1 showed a retention time of $7.9 \mathrm{~min}$, UV $\lambda_{\max }$ of 222 and $326 \mathrm{~nm}, m / z$ (int.) $[\mathrm{M}+\mathrm{H}]^{+} \mathrm{m} / z$ 355,1035. The compound 1 was identified as chlorogenic acid after a comparison with the theoretical exact mass of the protonated molecule (calculated as 355.1029, error 1,6 ppm). In

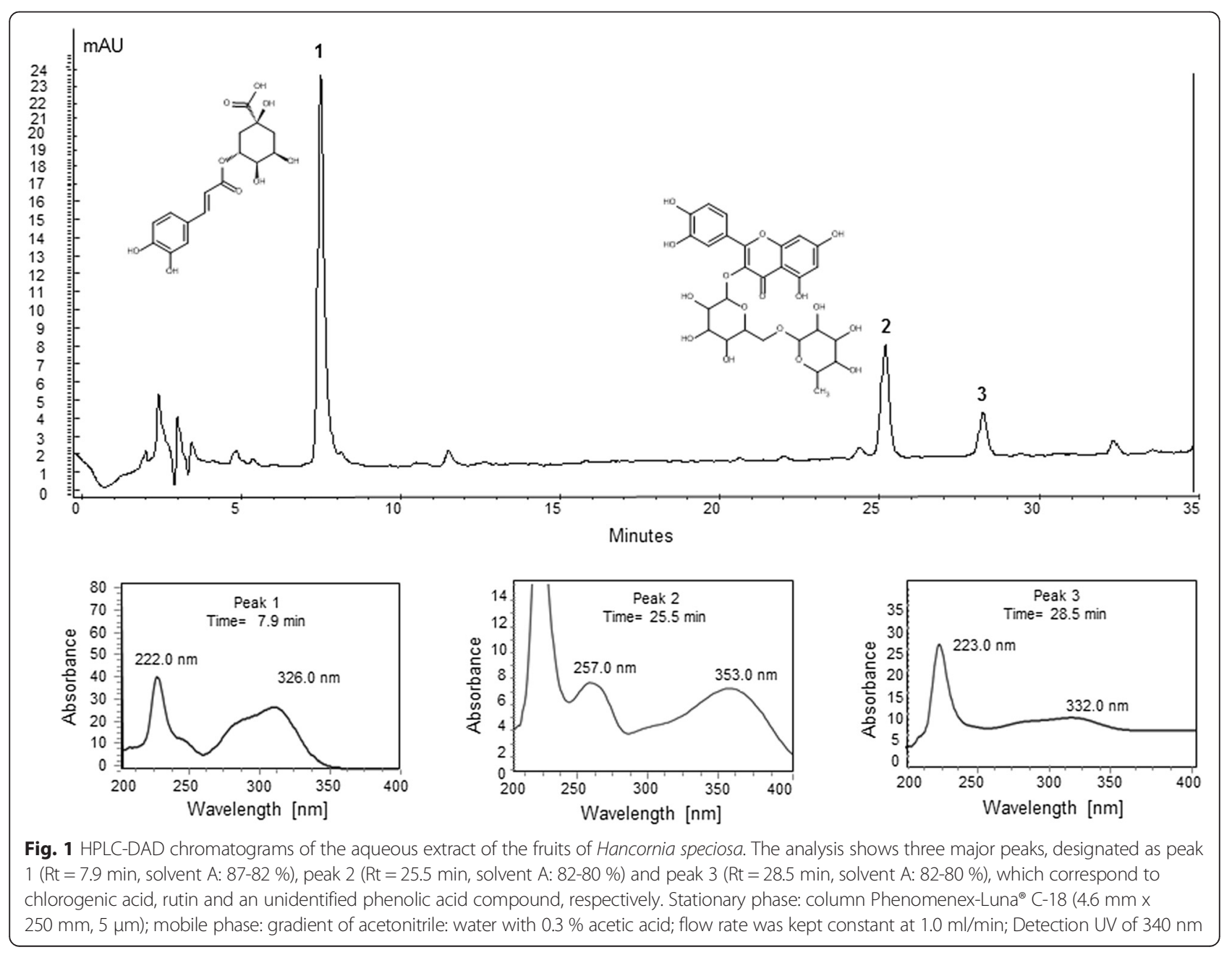


addition, the protonated molecule afforded the typical fragment ion $[\mathrm{M}+\mathrm{H}-192]^{+}$at $m / z 163$, which is attributed to the loss of quinic acid moiety. The peak 2 showed a retention time of $25.5 \mathrm{~min}$, UV $\lambda_{\max }$ of 257 and $353 \mathrm{~nm}, \mathrm{~m} /$ $z$ (int.) $[\mathrm{M}+\mathrm{H}]^{+} \mathrm{m} / z 611$ (protonated molecule) and the fragments at $m / z 465$ and 303 . The compound 2 was identified as rutin and its exact mass was calculated as $\mathrm{m} / \mathrm{z}$ 611.1607, (theoretical exact mass: 611.1612 error, 0,8 ppm). The fragments were in agreement with the ion $[\mathrm{M}+\mathrm{H}-$ $146]^{+}$at $m / z 465$, which is attributed to the loss of rhamnose moiety and a protonated aglycone ion $[\mathrm{M}+\mathrm{H}$ $146-162]^{+}$, whereas the loss of $308 \mathrm{u}$ corresponds to a rhamnose $(146 \mathrm{u})$ plus a glucose $(162 \mathrm{u})$ moiety. The LCMS analyses were compared with MassBank database (http://www.massbank.jp).

Evaluation of rutin, chlorogenic acid and aqueous extract of the fruits of Hancornia speciosa in carrageenaninduced peritonitis model

The anti-inflammatory activity of the aqueous extract, chlorogenic acid and rutin was evaluated using the carrageenan-induced peritonitis model. As expected, the animals treated intravenously (i.v.) with saline and thirty minutes later with the intraperitoneal (i.p.) administration of carrageenan exhibited a severe cell migration to the peritoneal cavity, as well as an increased production of IL-1 $\beta$, IL-6, IL-12 and TNF- $\alpha$. All groups treated (i.v.) with different doses $(20,30$ or $40 \mathrm{mg} / \mathrm{kg})$ of the extract, rutin and chlorogenic acid at doses of $2,2.5$ or $5 \mathrm{mg} / \mathrm{kg}$, showed a significant inhibition of cell migration into the peritoneal cavity when compared to those of the groups treated with saline (i.v.) and carrageenan (i.p.) (Fig. 2a). When only the extract $(40 \mathrm{mg} / \mathrm{kg}$ ) was administered intravenously, without the injection of carrageenan, inflammation could not be induced. The different doses $(20,30$ or $40 \mathrm{mg} / \mathrm{kg}$ ) of the extract, as well as rutin and chlorogenic acid at doses of $2,2.5$ or $5 \mathrm{mg} / \mathrm{kg}$, significantly inhibited the production of cytokines IL-1 $\beta$ (Fig. $2 b$ ), IL-6 (Fig. 2c), IL-12 (Fig. 2d) and TNF- $\alpha$ (Fig. 2e). In addition, the reduction in the total number of leukocytes and the decrease in the production of cytokines in the group treated with dexamethasone were very similar to those treated with the extract, rutin and chlorogenic acid.

\section{Evaluation of rutin, chlorogenic acid and the aqueous extract of the fruits of Hancornia speciosa in xylene- induced ear edema model}

The effects of rutin, chlorogenic acid and extract on edema formation in mice were investigated using xyleneinduced ear edema model. The groups treated (i.p.) with 40, 50 and $60 \mathrm{mg} / \mathrm{kg}$ of the extract showed a suppression of the xylene-induced ear edema of 78.36, 81.07 and $73.18 \%$, respectively. These results were similar to those of the group treated with dexamethasone (i.p.) at a dose of
$0.5 \mathrm{mg} / \mathrm{kg}$ (79.66 \%). When only the extract $(60 \mathrm{mg} / \mathrm{kg})$ was administered intraperitoneally, without xylene, it was observed that both ears showed similar weights, with the right and left ears weighing $28.40 \mathrm{mg}( \pm 0.8540)$ and $27.50 \mathrm{mg}( \pm 1.067)$, respectively. These results suggest that the aqueous extract alone is not able to induce the formation of edema. The group treated with rutin (i.p.) received doses of 2.5, 5 and $10 \mathrm{mg} / \mathrm{kg}$, which were able to reduce the edema in 76.94, 83.29 and $97.78 \%$, respectively, whereas the groups treated (i.p.) with chlorogenic acid with doses of $10,12.5$ and $15 \mathrm{mg} / \mathrm{kg}$ showed a reduction of $85.82,83.17$ and $79.84 \%$ of the edema, respectively (Table 1).

\section{Evaluation of rutin, chlorogenic acid and the aqueous extract of the fruits of Hancornia speciosa in zymosan- induced air pouch model}

After zymosan was injected into the animal's air pouch, acute inflammation was induced, whose response was characterized by leukocyte migration and plasma exudation to the cavity. Mice treated (i.p.) with saline and thirty minutes later with subcutaneous (s.c.) administration of zymosan showed intense leukocyte migration towards the animals' pouch. However, all the groups treated (i.p.) with different doses $(40,50$ or $60 \mathrm{mg} / \mathrm{kg}$ ) of the extract showed a significant inhibition of leukocyte migration compared with the group that received only saline (i.p.) and zymosan (s.c.). When only the extract $(60 \mathrm{mg} / \mathrm{kg})$ was administered intraperitoneally, without receiving the injection of zymosan, it was observed that cellular migration into the cavity was similar to that of the saline group, which indicates that the extract alone is not able to induce leukocytes migration and hence inflammation. The groups treated (i.p.) with rutin at doses of $2.5,5$ and $10 \mathrm{mg} / \mathrm{kg}$ and chlorogenic acid at doses of $10,12.5$ and $15 \mathrm{mg} / \mathrm{kg}$ showed a significant inhibition of cell migration (Fig. 3a).

After evaluating the effect of three different doses of rutin, chlorogenic acid and extract, their effects on the kinetics $(6,24$ and $48 \mathrm{~h})$ of cell migration and differential count were evaluated using a fixed dose of each of these compounds. The administration of zymosan (s.c.) induced a marked increase in cell migration to the back of the mice at all time points $(6,24$ and $48 \mathrm{~h})$. However, the previous treatment with the aqueous extract (i.p.) at a dose of $50 \mathrm{mg} / \mathrm{kg}$, rutin (i.p.) at $2.5 \mathrm{mg} / \mathrm{kg}$ and chlorogenic acid (i.p.) at $10 \mathrm{mg} / \mathrm{kg}$ was able to significantly inhibit leukocyte migration during all the time points, which was in fact, very similar to that of the group treated with dexamethasone (i.p.) at a dose of $2.0 \mathrm{mg} / \mathrm{kg}$. Thus, the treated-groups showed a marked decrease in the leukocyte migration even $48 \mathrm{~h}$ after zymosan inoculation (Fig. 3b). Furthermore, the extract (i.p.) at a dose of $50 \mathrm{mg} / \mathrm{kg}$, rutin (i.p.) at a dose of $2.5 \mathrm{mg} / \mathrm{kg}$ and 

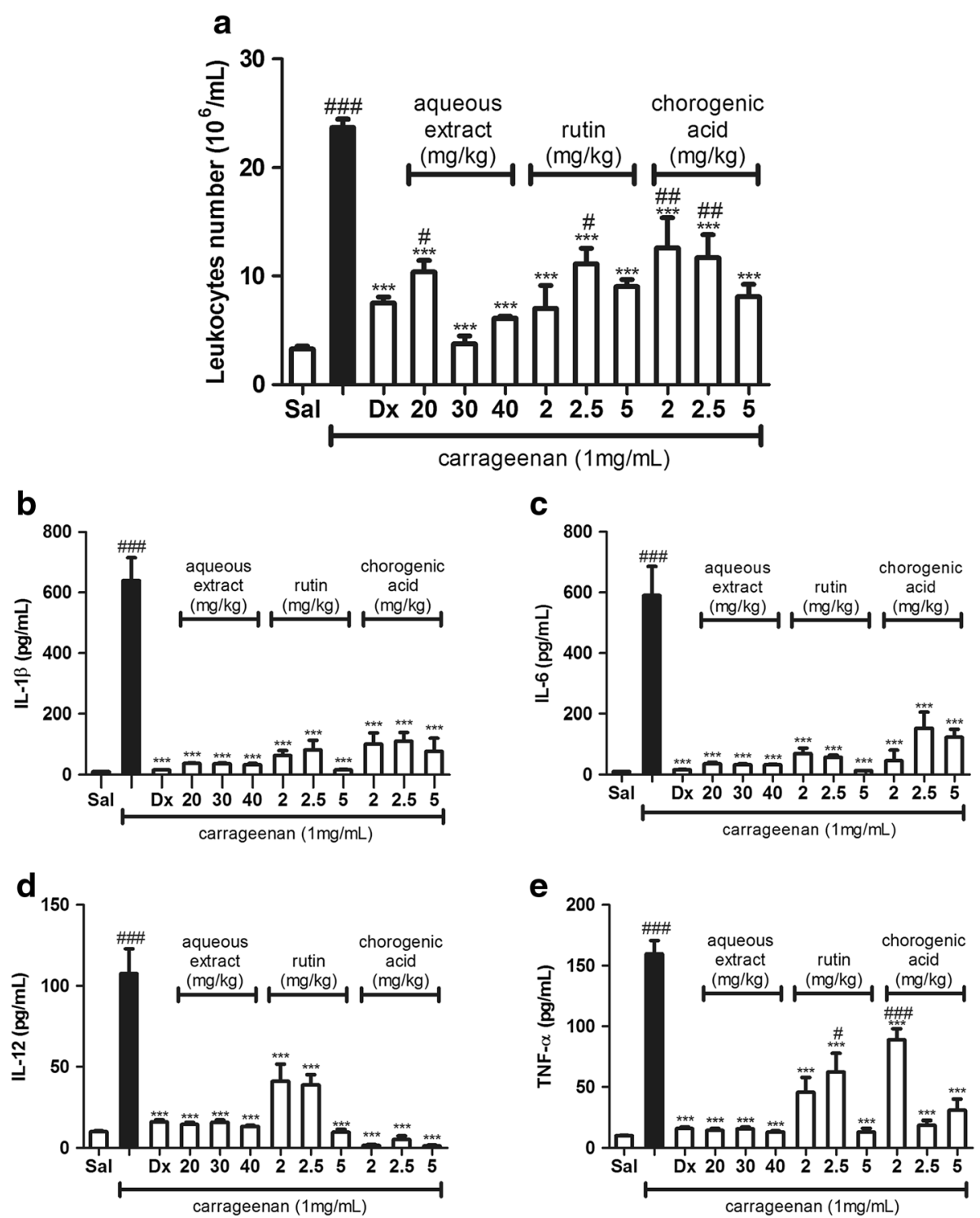

Fig. 2 Effect of the aqueous extract from the fruits of Hancornia speciosa, rutin and chlorogenic acid in carrageenan-induced peritonitis model. BALB/C mice were treated (i.v.) with saline, aqueous extract at doses of 20,30 or $40 \mathrm{mg} / \mathrm{kg}$, rutin, chlorogenic acid at the dose of 2, 2.5 or 5 and with dexamethasone (i.p.) at the dose of $0.5 \mathrm{mg} / \mathrm{kg}$, thirty minutes after carrageenan $(1 \mathrm{mg} / \mathrm{mL}$ ) or saline $(1 \mathrm{~mL})$ administration (i.p). After $4 \mathrm{~h}$, peritoneal lavage with saline was performed and leucocytes count was performed using a Neubauer chamber (a). The supernatants were collected for the determination of IL-1 1 (b), IL-6 (c), IL-12 (d), and TNF-a (e), which was performed using an enzyme-linked immunosorbent assay. The solid column (black bar) represents the groups that received saline solution (i.v.) followed by intraperitoneal administration of carrageenan 30 min later. Each column represents the mean of the values obtained from five animals, and the vertical lines indicate the standard errors of the mean (SEM). ${ }^{\# \# \#} p<0.001$ compared with the group treated with saline; ${ }^{* * *} p<0.001$ compared with the carrageenan group. Sal: saline $(0.9 \mathrm{mg} / \mathrm{mL})$; Dx: dexamethasone $(0.5 \mathrm{mg} / \mathrm{kg})$

chlorogenic acid (i.p.) at a dose of $10 \mathrm{mg} / \mathrm{kg}$ reduced the number of polymorphonuclear cells at all time points $(6$, 24 and 48 h) (Fig. 3c). The number of mononuclear cells was analyzed, but they did not show statistical difference between groups (data not shown).

\section{Discussion}

In the present study, phytochemical analysis of the extract from the $H$. speciosa fruits indicated the presence of chlorogenic acid and rutin (Fig. 1). The presence of chlorogenic acid has also been demonstrated by [39], where six phenolic acids (chlorogenic, ferulic, gallic, pcoumaric, protocatechuic and vanillic acids) were identified by ultra performance liquid chromatography (UPLC) in the Brazilian tropical fruits "mangaba" (H. speciosa Gomes) and "umbu" (Spondias tuberosa Arruda Camara) [39]. Rutin and chlorogenic acid have been used for their pharmacological properties such as anti-oxidant, anti- 
Table 1 Anti-edematogenic effect of rutin, chlorogenic acid and the aqueous extract from the fruits of Hancornia speciosa in xylene-induced ear edema model

\begin{tabular}{llll}
\hline Groups (treatment i.p.) & Dose $(\mathrm{mg} / \mathrm{kg})$ & Difference $(\mathrm{mg})$ & Inhibition (\%) \\
\hline Saline & - & $32.450 \pm 2.603$ & \\
Dexamethasone & 0.5 & $6.600 \pm 2.448^{* * *}$ & 79.66 \\
Aqueous extract & 40 & $7.020 \pm 3.820^{* * *}$ & 78.36 \\
Aqueous extract & 50 & $6.140 \pm 2.385^{* * *}$ & 81.07 \\
Aqueous extract & 60 & $8.700 \pm 2.719^{* * *}$ & 73.18 \\
Rutin & 2.5 & $7.480 \pm 2.221^{* * *}$ & 76.94 \\
Rutin & 5 & $5.420 \pm 2.328^{* * *}$ & 83.29 \\
Rutin & 10 & $0.720 \pm 1.253^{* * *}$ & 97.78 \\
Chlorogenic acid & 10 & $4.600 \pm 2.795^{* * *}$ & 85.82 \\
Chlorogenic acid & 12.5 & $5.460 \pm 2.579^{* * *}$ & 83.17 \\
Chlorogenic acid & 15 & $6.540 \pm 3.917^{* * *}$ & 79.84
\end{tabular}

Values are mean \pm standard deviation (S.D.), $n=5,{ }^{* *} p<0.001$, tested-group compared to saline-treated group

carcinogenic and anti-inflammatory [40-42]. Regarding the anti-inflammatory activity of Hancornia speciosa, there is one study that reported this property, but it was performed on its latex [19] and for the best of our knowledge, no study has been performed on its fruits. Our previous in vitro study demonstrated that different concentrations $(0.25,0.375,0.5,0.75,1,1.25$ and $1.75 \mathrm{mg} / \mathrm{mL})$ of aqueous extracts from the fruits of Hancornia speciosa did not present significant toxicity in $3 \mathrm{~T} 3$ cells. Thus, the data suggest that the doses of $H$. speciosa extracts used in this study are safe. The lack of cytotoxicity effect of Hancornia speciosa fruits was corroborated with the cytotoxicity effects of $H$. speciosa latex on the root meristem cells of Allium cepa [43].

Thus, the anti-inflammatory effects of the extract of the $H$. speciosa fruits as well as rutin and chlorogenic acid were evaluated using in vivo inflammatory models. The carrageenan-induced peritonitis involves the acute inflammation process that takes place through the release of histamine, serotonin and bradykinin, which lead to an increase in the vascular permeability and prostaglandins production [44, 45]. The increased vascular permeability and higher production of inflammatory mediators resulted in a gradual increase in fluid leakage and a higher number of cells that migrated into the animal's peritoneal cavity, especially neutrophils, which are capable of producing cytokines that are associated with the inflammatory process. If this process is not controlled, it can cause serious infection that often leads to multiple organ failure, septicemia and mortality [46]. This study showed that the aqueous extract, rutin and chlorogenic acid exerted an anti-inflammatory effect at all tested doses. They were able to reduce cell recruitment into the peritoneal cavity of mice and inhibited the

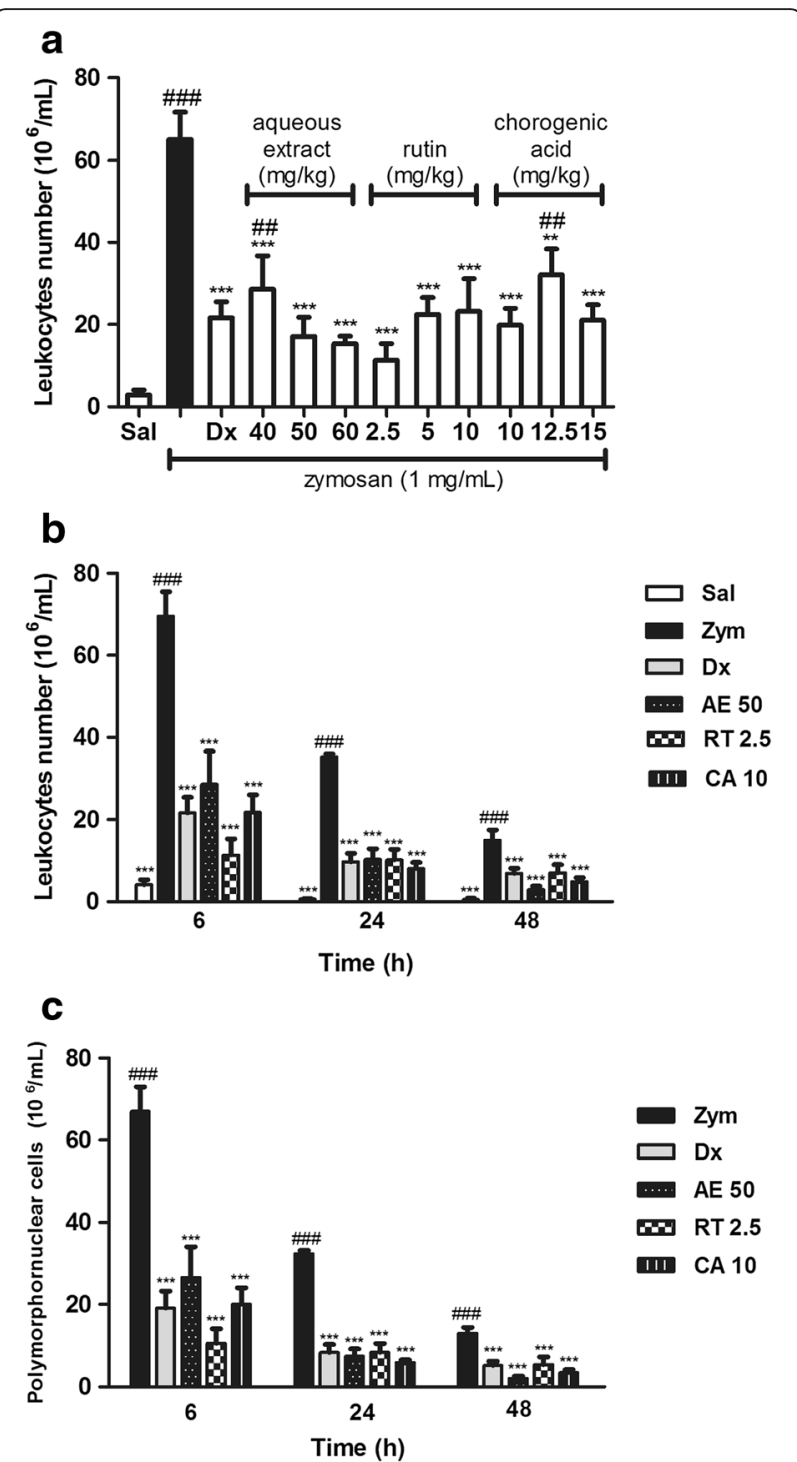

Fig. 3 Effect of the aqueous extract from the fruits of Hancornia speciosa in zymosan-induced air pouch model. Swiss mice were treated (i.p.) with saline, aqueous extract at doses of 40,50 or 60 , rutin, chlorogenic acid at the dose of 2, 2.5 or 5 and with dexamethasone ( $2.0 \mathrm{mg} / \mathrm{kg}$ ), thirty minutes after subcutaneous (s.c.) injection of zymosan solution $(1 \mathrm{mg} / \mathrm{mL})$ or saline $(1 \mathrm{~mL})$ into the animals air pouch. After six hours, the exudate was harvested from each air pouch by lavage with $2 \mathrm{~mL}$ of saline and leucocytes count was performed using a Neubauer chamber (a). At 6, 24 and $48 \mathrm{~h}$ after zymosan administration, the dose of $50 \mathrm{mg} / \mathrm{kg}$ of aqueous extract, $2.5 \mathrm{mg} / \mathrm{kg}$ of rutin and $10 \mathrm{mg} / \mathrm{kg}$ chlorogenic acid were chosen to perform the experiment of leucocytes cell migration kinetics (b) and polymorphonuclear cells migration kinetics (c). The solid column (black bar) represents the group that received saline solution (i.p.) followed by subcutaneous administration of zymosan 30 min later. Each column represents the mean of the values obtained from five animals, and the vertical lines indicate the standard errors of the mean (SEM). ${ }^{\# \#} p<0.001$ compared with the control group (Sal); ${ }^{* *} p<0.001,{ }^{* *} p<0.01$ and ${ }^{*} p<0.05$, compared with the zymosan group (Zym). Sal: saline $(0.9 \mathrm{mg} / \mathrm{mL})$; Zym: zymosan $(1 \mathrm{mg} / \mathrm{mL}) ;$ Dx: dexamethasone (2.0 mg/kg); AE: aqueous extract (50 mg/kg); RT: rutin (2.5 mg/kg); CA: chlorogenic acid (10 mg/kg) 
production of cytokines (IL-1 $\beta$, IL- 6 , IL-12 and TNF- $\alpha$ ). The mechanism involved in their anti-inflammatory activity is still unknown. However, there are hypotheses that can be suggested. Considering that a vascular endothelial cell contraction takes place at the moment of injury, it is likely that an increase in vascular permeability with the production of exudate eventually occurs. Such vascular events induce the activation of inflammatory mediators, followed by the recruitment and adhesion of leukocytes to the inflammation site. These mechanisms are regulated by both cell adhesion molecules and by the production of inflammatory cytokines [21, 47]. Therefore, it seems that the aqueous extract of $H$. speciosa fruits and its bioactive molecules inhibited the inflammatory mediators involved in the carrageenan-induced inflammation, such as histamine, serotonin, kinins and prostaglandins, which are responsible for inducing vasodilatation and formation of exudate in the peritoneal cavity. In addition, they could have inhibited the leukocytes receptors that connect with intercellular adhesion molecules that activate endothelial cells, blocking the migration of the leukocytes to the inflammation site. If these inflammatory mediators and vascular events are blocked or interrupted, the production of inflammatory cytokines will also be compromised.

Induction of ear edema was used as the primary model for acute inflammation, where xylene acted as the phlogistic agent, increasing vascular permeability with edema formation, which is one of the main signs of inflammation. This inflammation process is initiated by the action of mediators such as serotonin, acetylcholine, histamine, bradykinin and prostaglandins, which release neuropeptides that activate its receptors, causing neurogenic inflammation [48]. One of the neuropeptides, called substance $\mathrm{P}$, is a potent vasodilator that acts by releasing nitric oxide from endothelial cells, which causes vasodilatation and plasma exudation, inducing the formation of edema [49]. In this study, it was demonstrated that the extract, rutin and chlorogenic acid were able to reduce at least $73 \%$ of the ear edema, which indicates a promising anti-phlogistic effect. Although the mechanism of action has not been elucidated, it seems that the extract have a membrane-stabilizing effect that reduces vasodilatation, as rutin reportedly improves the strength and integrity of blood vessel walls [50]. The other possibility is through an inhibitory effect over the inflammatory mediators that activate receptors that cause the neurogenic inflammation.

The zymosan-induced air pouch was another in vivo model that was used in this study to investigate the antiinflammatory properties of the extract, rutin and chlorogenic acid. Due to the fact that the injection of sterile air into the back of an animal forms a cell-lined cavity that resembles the synovial membrane, this model is considered to be similar to the inflammatory response of synovial tissue $[36,51]$. Zymosan is a polysaccharide derived from Saccharomyces cerevisiae yeasts, whose administration promotes an intense inflammatory reaction [52]. The results revealed that rutin, chlorogenic acid and the extract significantly reduced leukocytes migration to the pouch of the mice at all time points, even after $48 \mathrm{~h}$ of zymosan administration. In addition, significant reduction of polymorphonuclear cells, as well as an increase in the number of mononuclear cells shows the ability of the extract to control the inflammation by reducing the number of neutrophils at the inflammation site. The mechanism involved in the inhibition of inflammation by this extract is still unclear. There are reports in the literature that indicate that zymosan interacts with the toll-like receptor 2 (TLR-2). Zymosan is recognized by receptors (dectin-1) present in macrophages, neutrophils and $\mathrm{T}$ cells. After the recognition, it interacts with TLR-2. Studies suggest that the combined signaling of dectin- 1 and TLR-2 enhance the responses triggered by each receptor [53]. This interaction induces intracellular cascades that activates the selective recruitment of adapter proteins and induces the myeloid differentiation of gene 88 (MyD88), activating the transcription of the nuclear factor kappa B (NF-kB), which is responsible for the transcription of pro-inflammatory genes, resulting in the production of inflammatory cytokines and the expression of co-stimulatory molecules [54]. Previous reports have shown that rutin and chlorogenic acid have several pharmacological activities, especially anti-inflammatory $[40,42]$. Recent studies show that both chlorogenic acid and rutin inhibit the activation of NK-kB, suppressing the production of prostaglandin E2 by inhibiting the cyclooxygenase- 2 expression $[55,56]$. Thus, it seems reasonable to consider that these two secondary metabolites act synergically in this inflammation pathway. Other possibility is that the extract or its bioactive molecules can competitively inhibit the TLR- 2 or/and dectin- 1 receptor, suppressing the intracellular cascades of inflammation.

Moreover, the inhibition of cell migration towards the inflammation site can not be ruled out as another mechanism for the anti-inflammatory activity of Hancornia speciosa fruits. It is known that the inflammatory process occurs through the increase in the vascular permeability, as well through the migration and activation of polymorphonuclear cells, especially neutrophils [57]. Thus, it is possible that the bioactive molecules present in the aqueous extract of Hancornia speciosa fruits bind to receptors of endothelial cells, inhibiting the cell migration and the activation of inflammatory mediators involved in chemotaxis and diapedesis.

\section{Conclusion}

In conclusion, these findings demonstrate for the first time that the aqueous extract of the fruits of $H$. speciosa 
have a marked anti-inflammatory effect in animal models. Moreover, these results suggest that rutin and chlorogenic acid may play a critical role in controlling inflammatory events, contributing, at least in part, for the anti-inflammatory effect of $H$. speciosa fruits. However, additional studies are needed to show that other constituents present in the extract also contribute to the anti-inflammatory effect. Therefore, it seems reasonable to suggest that the extract may represent in the near future a new alternative or complementary option for treating inflammatory disorders.

\begin{abstract}
Abbreviations
$A E$, aqueous extract; $A N O V A$, one-way analysis of variance; $C A$, chlorogenic acid; DAD, diode array detector; Dx, dexamethasone; ELISA, enzyme-linked immunosorbent assay; ESI, electrospray ionization; HPLC, high performance liquid chromatography; i.p., intraperitoneal; i.v., intravenous; ICAMs, intercellular adhesion molecules; IL-12, interleukin 12; IL-1 $\beta$, interleukin 1-beta; IL-6, interleukin 6; LC, liquid chromatography; MS, mass spectrometry; MyD88, myeloid differentiation primary response gene 88; NF-kB, nuclear factor kappa B; NSAIDs, non-steroidal anti-inflammatory drugs; PGE2, prostaglandin E2; Rf, retention factor; RT, rutin; s.c., subcutaneous; SAIDs, steroidal anti-inflammatory drugs; Sal, saline $(0.9 \mathrm{mg} / \mathrm{mL})$; TLR-2, toll-like receptor 2; TNF-a, tumor necrosis factor alpha; Zym, zymosan
\end{abstract}

\section{Acknowledgments}

The authors thank CNPq, CAPES and FAPERN for financial support and acknowledge all participants for their valuable time and commitment to this study.

\section{Funding}

This research was supported by CNPq, financial support from FAPERN (PRONEM 003/2011) and CAPES (Toxinology 063/2010).

\section{Availability of data and materials}

Data are all contained within manuscript. The plant's materials for the study were identified and voucher specimens are deposited in the Herbarium of the Federal University of Rio Grande do Norte, Brazil.

\section{Authors' contributions}

MTR, MAOB, AAF, SMZ and MFFP conceived and designed the experiments. MTR, MAOB, AAF, MCJSL, RCLCA, TCS and JCT performed the experiments. MTR, MAOB, TCS, JCT, SMZ, NPL and MFFP analyzed the data. MAOB, NPL, AASJ, SMZ and MFFP contributed with reagents, materials and/or analytical tools. MTR, MAOB, AAF, MCJSL, RCLCA, TCS, JCT, NPL, SMZ and MFFP wrote the manuscript. MAOB, EPA, NPL, AASJ, SMZ and MFFP refined the manuscript for publication. All authors read and approved the final manuscript.

\section{Authors' information}

MFFP and NPL are CNPq fellowship-honored researchers.

\section{Competing interests}

The authors declare that they have no competing interests.

\section{Consent for publication}

This information is not relevant.

\section{Ethics approval and consent to participate}

All experimental protocols on animals in this study were complied with the standards for the care and use of experimental animals and were approved by the Animal Ethics Committee of the Universidade Federal do Rio Grande do Norte, Brazil ( $\left.N^{\circ} 008 / 2011\right)$.

\section{Author details}

'Departamento de Farmácia, Laboratório de Tecnologia e Biotecnologia Farmacêutica (TecBioFar), Faculdade de Farmácia, Centro de Ciências da Saúde, Universidade Federal do Rio Grande do Norte, Rua Gal. Gustavo Cordeiro de Farias, s/n, Petrópolis, CEP 59012-570 Natal, RN, Brazil.
2Departamento de Pós-graduação em Biotecnologia, Universidade Potiguar, Avenida Senador Salgado Filho, 1610, Lagoa Nova, CEP 59056-000 Natal, RN, Brazil. ${ }^{3}$ Departamento de Farmácia, Laboratório de Farmacognosia, Faculdade de Farmácia, Centro de Ciências da Saúde, Universidade Federal do Rio Grande do Norte, Rua Gal. Gustavo Cordeiro de Farias, s/n, Petrópolis, CEP 59012-570 Natal, RN, Brazil. ${ }^{4}$ Departamento de Física e Química, Núcleo de Pesquisas em Produtos Naturais e Sintéticos (NPPNS), Faculdade de Ciências Farmacêuticas de Ribeirão Preto, Universidade de São Paulo, Avenida do Café, s/n, Monte Alegre, CEP 14040-903 Ribeirão Preto, SP, Brazil.

Received: 15 February 2016 Accepted: 3 August 2016

Published online: 05 August 2016

\section{References}

1. Luiz-Ferreira A, Cola-Miranda M, Barbastefano V, Hiruma-Lima CA, Vilegas W, Souza Brito ARM. Should Anacardium humile St. Hil be used as an antiulcer agent? A scientific approach to the traditional knowledge. Fitoterapia. 2008:79:207-9.

2. Yaseen G, Ahmad M, Sultana S, Suleiman Alharrasi A, Hussain J, Zafar M, Shafiq-Ur-Rehman. Ethnobotany of Medicinal Plants in the Thar Desert (Sindh) of Pakistan. J Ethnopharmacol. 2015;163:43-59.

3. Calixto JB. Twenty-five years of research on medicinal plants in Latin America. A personal view. J Ethnopharmacol. 2005;100:131-4.

4. Koch I, Rapini A, Simões AO, Kinoshita LS, Spina AP, Castello ACD. Apocynaceae in Lista de Espécies da Flora do Brasil. Jardim Botânico do Rio de Janeiro. Disponível em: (http://floradobrasil.jbrj.gov.br/jabot/floradobrasil/ FB15558) (Accessed 06 June 2015).

5. Rodrigues VEG, Carvalho DA. Levantamento Etnobotânico De Plantas Medicinais No Domínio do Cerrado Na Região Do Alto Etnobotanical. Ciênc Agrotec. 2001;25:102-23.

6. Sampaio TS. Estudo Fitoquímico de Hancornia speciosa Gomes: Isolamento, Determinação Estrutural e Atividade Biológica. 190f. Dissertação (Mestrado em Química) - Universidade Federal de Sergipe, Sergipe;2008.

7. Almeida SP, Proença CEB, Sano SM, Ribeiro JF. Cerrado: Espécies vegetais úteis. EMBRAPA, Planaltina;1998:38.

8. Grandi TMS, Lima-Filho FM, Ferreira SMA. Levantamento das plantas medicinais de Grão o Mogol. Oréades. 1982:8:116-25.

9. Hirschmann GS, Arias AR. A Survey of medicinal plants of Minas Gerais, Brazil. J Ethnopharmacol. 1990;29:159-72.

10. Ferreira HC, Serra CP, Lemos VS, Braga FC, Cortes SF. Nitric oxide-dependent vasodilatation by ethanolic extract of Hancornia speciosa via phosphatidylinositol 3-kinase. J Ethnopharmacol. 2007;109:161-4.

11. Ferreira HC, Serra CP, Endringer DC, Lemos VS, Braga FC, Cortes SF. Endothelium-dependent vasodilation induced by Hancornia speciosa in rat superior mesenteric artery. Phytomedicine. 2007;14:473-8.

12. Silva GC, Braga FC, Lima MP, Pesquero JL, Lemos VS, Cortes SF. Hancornia speciosa Gomes induces hypotensive effect through inhibition of ACE and increase on NO. J Ethnopharmacol. 2011;137:709-13.

13. Endringer DC, Pezzuto JM, Braga FC. NF-kappaB inhibitory activity of cyclitols isolated from Hancornia speciosa. Phytomedicine. 2009;16:1064-9.

14. Endringer DC, Valadares YM, Campana PRV, Campos JJ, Guimarães KG, Pezzuto JM, Braga FC. Evaluation of Brazilian Plants on Cancer Chemoprevention Targets In Vitro. Phyther Res. 2010;24:928-33.

15. Pereira AC, Pereira ABD, Moreira CCL, Botion LM, Lemos VS, Braga FC, Cortes SF. Hancornia speciosa Gomes (Apocynaceae) as a potential anti-diabetic drug. J Ethnopharmacol. 2015;161:30-5.

16. Moraes TDM, Rodrigues CM, Kushima H, Bauab TM, Villegas W, Pellizzon CH, Brito ARMS, Hiruma-Lima CA. Hancornia speciosa: indications of gastroprotective, healing and anti-Helicobacter pylori actions. J Ethnopharmacol. 2008;120:161-8.

17. Rodrigues CM, Rinaldo D, Santos LC, Montoro P, Hiruma-Lima A, Brito ARMS, Piacente S, Pizza C, Vilegas W. Metabolic fingerprinting using direct flow injection electrospray ionization tandem mass spectrometry for the characterization of proanthocyanidins from the barks of Hancornia speciosa. Rapid Commun Mass Spectrom. 2007;21:1907-14.

18. Lima JP, Azevedo L, de Souza NJ, Nunes EE, Vilas Boas EVDB. First evaluation of the antimutagenic effect of mangaba fruit in vivo and its phenolic profile identification. Food Res Int. 2015;75:216-24.

19. Marinho DG, Alviano DS, Matheus ME, Alviano CS, Fernandes PD. The latex obtained from Hancornia speciosa Gomes possesses anti-inflammatory activity. J Ethnopharmacol. 2011;135:530-7. 
20. Carvalho W, Lemônica L. Artigo de Revisão Mecanismos Celulares e Moleculares da Dor Inflamatória. Modulação Periférica e Avanços Terapêuticos. Rev Bras Anestesiol. 1998:48:137-58.

21. Schmid-Schönbein GW. Analysis of inflammation. Annu Rev Biomed Eng. 2006;8:93-131

22. Tayal V, Kalra BS. Cytokines and anti-cytokines as therapeutics - An update. Eur J Pharmacol. 2008;579:1-12.

23. Scott A, Khan KM, Duronio V. What is "inflammation"? Are we ready to move beyond Celsus? Br J Sports Med. 2004;38:248-9.

24. Sostres C, Gargallo CJ, Arroyo MT, Lanas A. Adverse effects of non-steroida anti-inflammatory drugs (NSAIDs, aspirin and coxibs) on upper gastrointestinal tract. Best Pract Res Clin Gastroenterol. 2010;24:121-32.

25. Whitehouse MW. Anti-inflammatory glucocorticoid drugs: Reflections after 60 years. Inflammopharmacology. 2011;19:1-19.

26. Plaeger SF. Clinical immunology and traditional herbal medicines. Clin Diagn Lab Immunol. 2003;10:337-9.

27. Saklani A, Kutty SK. Plant-derived compounds in clinical trials. Drug Discov Today. 2008;13:161-71.

28. Itokawa H, Morris-Natschke SL, Akiyama T, Lee KH. Plant-derived natural product research aimed at new drug discovery. J Nat Med. 2008;62:263-80.

29. Kolewe ME, Gaurav V, Roberts SC. Pharmaceutically active natural product synthesis and supply via plant cell culture technology. Mol Pharm. 2008;5:243-56.

30. Kolaczkowska E, Koziol A, Plytycz B, Arnold B. Inflammatory macrophages, and not only neutrophils, die by apoptosis during acute peritonitis. Immunobiology. 2010;215:492-504.

31. Magalhães A, Santos GB, Verdam MCDS, Fraporti L, Malheiro A, Lima ES, Dos-Santos MC. Inhibition of the inflammatory and coagulant action of Bothrops atrox venom by the plant species Marsypianthes chamaedrys. J Ethnopharmacol. 2011;134:82-8.

32. Cunha FQ, Souza GEP, Souza CAM, Cerqueira BCS, Ferreira SH. In vivo blockage of neutrophil migration by LPS is mimicked by a factor released from LPS-stimulated macrophages. Br J Exp Pathol. 1989;70:1-8.

33. Parveen Z, Deng Y, Saeed MK, Dai R, Ahamad W, Yu Y. Antiinflammatory and Analgesic Activities of Thesium chinense Turcz Extracts and its Major Flavonoids, Kaempferol and Kaempferol-3-O-glucoside. Pharm Soc Japan. 2007:127:1275-9.

34. Pinheiro MMG, Miltojević AB, Radulović NS, Abdul-Wahab IR, Boylan F, Fernandes PD. Anti-Inflammatory Activity of Choisya ternata Kunth Essential Oil, Ternanthranin, and Its Two Synthetic Analogs (Methyl and Propyl N-Methylanthranilates). PLoS One. 2015:10:e0121063.

35. Vigil SVG, de Liz R, Medeiros YS, Fröde TS. Efficacy of tacrolimus in inhibiting inflammation caused by carrageenan in a murine model of air pouch. Transpl Immunol. 2008;19:25-9.

36. Yoon SY, Kwon YB, Kim HW, Roh DH, Kang SY, Kim CY, Han HJ, Kim KW, Yang IS, Beitz AJ, Lee JH. Intrathecal neostigmine reduces the zymosaninduced inflammatory response in a mouse air pouch model via adrenomedullary activity: involvement of spinal muscarinic type 2 receptors. Neuropharmacology. 2005;49:275-82.

37. Fialho EMS, Maciel MCG, Silva ACB, Reis AS, Karine A, Assunção M, Fortes TS, Silva LA, Guerra RNM, Kwasniewski FH, Nascimento FRF. Immune cells recruitment and activation by Tityus serrulatus scorpion venom. Toxicon. 2011;58:480-5

38. Wagner H, Bladt S. Plant Drug Analysis. New York: Springer; 1996

39. Gomes EB, Ramanho SR, Gualberto NC, Miranda RCM, Nigam N, Norain N. A Rapid Method for Determination of Some Phenolic Acids in Brazilian Tropical Fruits of Mangaba (Hancornia speciosa Gomes) and Umbu (Spondias tuberosa Arruda Camara) by UPLC. Journal of Analytical Sciences, Methods and Instrumentation. 2013;3:1-10.

40. Lima MCJDS, Bitencourt MAO, Furtado AA, Oliveira Rocha HA, Oliveira RM, Silva-Júnior AA, Tabosa Do Egito ES, Tambourgi DV, Zucolotto SM, FernandesPedrosa MDF. Ipomoea asarifolia neutralizes inflammation induced by Tityus serrulatus scorpion venom. J Ethnopharmacol. 2014;153:890-5.

41. Xu Y, Chen J, Yu X, Tao W, Jiang F, Yin Z, Liu C. Protective effects of chlorogenic acid on acute hepatotoxicity induced by lipopolysaccharide in mice. Inflamm Res. 2010;59:871-7.

42. Zhang $X$, Huang H, Yang T, Ye Y, Shan J, Yin Z, Luo L. Chlorogenic acid protects mice against lipopolysaccharide-induced acute lung injury. Injury. 2010;41:746-52

43. Ribeiro TP, Sousa TR, Arruda AS, Peixoto N, Gonçalves PJ, Almeida LM. Evaluation of cytotoxicity and genotoxicity of Hancornia speciosa latex in Allium cepa root model. Braz J of Biol. 2016;76:1-5.
44. Syam S, Bustamam A, Abdullah R, Sukari MA, Hashim NM, Mohan S, Looi CY, Wong WF, Yahayu MA, Abdelwahab SI. $\beta$ Mangostin suppress LPS-induced inflammatory response in RAW 264.7 macrophages in vitro and carrageenan-induced peritonitis in vivo. J Ethnopharmacol. 2014;153:435-45.

45. Vinegar R, Schreiber W, Hugo R. Biphasic Development of carrageenin edema in rats. J Pharmacol Exp Ther. 1969;166:96-103.

46. Larche J, Lancel S, Hassoun SM, Favory R, Decoster B, Marchetti P, Chopin C, Neviere R. Inhibition of Mitochondrial Permeability Transition Prevents Sepsis-Induced Myocardial Dysfunction and Mortality. J Am Coll Cardiol. 2006;48:377-85.

47. Hopkins SJ. The pathophysiological role of cytokines. Leg Med. 2003:5:45-57.

48. Banki E, Hajna Z, Kemeny A, Botz B, Nagy P, Bolcskei K, Toth G. The selective PAC1 receptor agonist maxadilan inhibits neurogenic vasodilation and edema formation in the mouse skin. Neuropharmacology. 2014;85:538-47.

49. Barry CM, Helps SC, Den HCV, Vink R. Characterizing the role of the neuropeptide substance $P$ in experimental subarachnoid hemorrhage. Brain Res. 2011;1389:143-51.

50. Pathak D, Pathak K, Singla AK. Flavonoids as medicinal agents: recent advances. Fitoterapia. 1991;557:371-89.

51. Cabrera PV, Blanco G, Gravisaco MJ, Alvarez E, Hajos S. Zymosan Modulates CD44 Isoform Expression in a Murine Model of Inflammation Resembling Rheumatoid Arthritis Synovitis. J Rheumatol. 2001:28:944-9.

52. Makni-Maalej K, Chiandotto M, Hurtado-Nedelec M, Bedouhene S, Gougerot-Pocidalo MA, Dang PMC, El-Benna J. Zymosan induces NADPH oxidase activation in human neutrophils by inducing the phosphorylation of p47phox and the activation of Rac2: Involvement of protein tyrosine kinases, PI3Kinase, PKC, ERK1/2 and p38MAPkinase. Biochem Pharmacol. 2013:85:92-100

53. Taylor PR, Brown GD, Reid DM, Willment JA, Martinez-Pomares L, Gordon S, Wong SYC. The Glucan Receptor, Dectin-1, Is Predominantly Expressed on the Surface of Cells of the Monocyte/Macrophage and Neutrophil Lineages. J Immunol. 2002;169:3876-82.

54. Guerrero ATG, Cunha TM, Verri W, Gazzinelli RT, Teixeira MM, Cunha FQ, Ferreira SH. Toll-like receptor 2/MyD88 signaling mediates zymosan-induced joint hypernociception in mice: Participation of TNF-a, IL-1 $\beta$ and CXCL1/KC. Eur J Pharmacol. 2011;674:51-7.

55. Choi S, Lim T, Kyung M, Kim Y, Kim J, Joo N, Su T, Park J, Hun M, Won K Rutin inhibits B [a] PDE-induced cyclooxygenase-2 expression by targeting EGFR kinase activity. Biochem Pharmacol. 2013:86:1468-75.

56. Shan J, Fu J, Zhao Z, Kong X, Huang H, Luo L, Yin Z. Chlorogenic acid inhibits lipopolysaccharide-induced cyclooxygenase-2 expression in RAW264.7 cells through suppressing NF-kappaB and JNK/AP-1 activation. Int Immunopharmacol. 2009;9:1042-8.

57. Pick R, Brechtefeld D, Walzog B. Intraluminal crawling versus interstitial neutrophil migration during inflammation. Mol Immunol. 2013;55:70-5.

\section{Submit your next manuscript to BioMed Central and we will help you at every step:}

- We accept pre-submission inquiries

- Our selector tool helps you to find the most relevant journal

- We provide round the clock customer support

- Convenient online submission

- Thorough peer review

- Inclusion in PubMed and all major indexing services

- Maximum visibility for your research

Submit your manuscript at www.biomedcentral.com/submit 